\title{
Orthopaedic Surgery during COVID pandemic and consequent Changes in our professional environment
}

\author{
Marius M. Scarlat ${ }^{1,2} \cdot$ Andreas F. Mavrogenis $^{3}$
}

Published online: 20 August 2020

(C) SICOT aisbl 2020

The medical profession was thrilled and faced in first line the changes of the society during the coronavirus crisis and pandemic. $[1,2,3,4,5,6]$ The world experienced stupor and slowdown of major economic activities. Political and social regulations were imposed. All medical specialties had to adapt and observations from our corresponding members and authors worldwide pointed out the changes in our ways of managing different medical conditions including emergency, trauma, transplantation [7] and tumor [8], cases that could not wait. The lockdown and changes in the workflow of medical centers created new challenges for the teams in all specialties, mainly in centers responsible for trauma or tumor and that were supposed to manage patients with unknown infection status. Anesthesiologists were at risk as they were supposed to act on the upper respiratory ways, intubate and ventilate cases with unknown viral charges. This resulted in casualties and morbidity by viral infection in several colleagues and some colleagues sadly and tragically lost their lives. The medical profession paid a high tribute to the pandemic with lethal cases and major stress exposure for the colleagues in the teams. $[9,10,11]$ A special issue was released in August 2020 and included scientific reports from colleagues working in pandemic conditions [12]. All papers showed that the activity decreased, by one side because of the lockdown that kept industry and car traffic at the lowest rhythm but also because hospital regulations that imposed work shortages and security issues. Scheduled procedures were postponed but also "not life threatening trauma" resulting in unfair access

Marius M. Scarlat

mscarlat@gmail.com

1 Clinique Chirurgicale St Michel, Toulon, France

2 Group ELSAN, Paris, France

3 First Department of Orthopaedics, National and Kapodistrian University of Athens, School of Medicine, 41 Ventouri Str., 15562 Athens, Greece to health care in many services and finally creating secondary pathologies that ware even more difficult to treat in a later phase such as pseudarthrosis, malunions, impaired bone and joint function [13]. The decision to postpone or to treat conservatively these cases was finally the surgeon's responsibility because the real deciders, hospital administrators, health management public leaders and insurance companies were presenting the decisional process as something that was more related to a "recommendation" and that finally each health professional was free to decide on the treatment choices. This lack of precision resulted in a significant number of cases that required additional treatment, revision or reconstruction and here we could also include cases of tumor or dysplasia pathologies that were declined or postponed treatment resulting in life-threatening situations. Cases like "this patient have a severe fracture but he is virus-positive, asymptomatic, what should we do, how we proceed?" Some services with a good logistic cover were able to proceed to chest CT-scan screening for all the cases requiring emergency treatment and this is probably one logic and humanitarian attitude in offering equal access to health care [14,15], others did the convenient treatment including surgery to all the patients managing from the medical side all the cases as they were potentially virus-positive and taking the appropriate anesthesiology and prevention methods. However, many services including big and well-equipped centers just postponed the surgery, waiting for the appropriate time to proceed. Overall the lockdown resulted in changes of methods in patients care, including the augmentation of virtual and internet clinics, decrease of consultations and clinics for degenerative or orthopaedic pathologies and ultimately decrease of the scheduled surgical activity. This non-contact policy resulted in the upgrading of the computer tools for virtual clinics, virtual meetings and the use of the artificial intelligence for prevention. [16,17,18]

A direct consequence of the virus crisis and activity drop was the uprising of the communication, writing, webinars, virtual conferences and talks. We experienced this with "International Orthopaedics" with an unprecedented number 
of submitted papers during the pandemic lockdown. Some of the papers submitted are old research that colleagues would propose for publication because they found finally the time to edit and submit. Some papers describe the virus crisis in the local conditions, those papers bring similar data, showing that the work load changed and because of the restrictions in society the cases of trauma or degenerative conditions decreased. Countries that were in the first line to face pandemic published valuable epidemiologic data $[19,20,21,22,23]$

Face-to-face meetings were postponed for months and maybe more. The industry faced a strong diminution of implant use and postponed indefinitely the participation to scientific events, meetings and congresses.

What comes next? Shall we adapt and work in the new conditions, living with the virus, waiting for the development of new vaccines or specific methods of treatment or move forward in the old way? Manage every new case as a potential virus carrier; take personal incentives as health professionals deciding about priorities? Work-related stress hit the healthcare providers and it takes time to educate the teams for facing new rules and conditions [24]. Orthopaedic surgeons follow general lines of public health and hospital and public health policy should be respected. Infection management rules and regulations should prevail, however the protection of our teams is essential and should come first, wear the appropriate equipment, test all the admitted cases, protect our anesthesiologists and nurses, protect the patients, follow the security hygiene rules in the operating areas and within the hospital facilities. Use computers for communications and keep distances. There are many variables in the evaluation of a pandemic crisis. The general population could be more or less resilient and the economy reacts sometimes in a paradoxical way. Countries that released the social distancing rules too early are facing a growth of the contaminations that could potentially become harmful. Orthopaedic surgery is a part of the general health system and is depending on a heavy technical and logistic platform including pharmaceuticals delivery, functional operating area facilities, air-cleaning systems, qualified persons availability and devotion, implants, sterilization and so many other factors that can make the difference between a highly successful procedure and a catastrophe.

International Orthopaedics is the official journal of SICOT and represents along with the annual World Orthopaedic Congress the academic side of our multinational organization. Today we are facing common threats and existential issues. We adapted by making a substantial re-organization of the SICOT Head Office with a greater focus on membership affairs and benefits. Significant efforts are underway to increase membership globally and to improve the academic profile of the organization. International Orthopaedics is the academic face of SICOT - what we turn to the world and by what we are largely judged by the orthopaedic community.
Because of the importance of International Orthopaedics to SICOT the Editorial Board is pushing constantly for higher academic standards in our publications and increasing the number of papers published while maintaining our obligation to represent fairly the diversity of SICOT membership. Accordingly manuscripts with varying levels of evidence are welcomed since individual surgeon experience may be extremely useful in development of similar programs elsewhere in the world. Recently the Board decided to open Editorial Offices in different geographic areas to facilitate the contact between our Deputy Editors and the colleagues in the regions. The Regional offices are opened with contacts that can be reached by e-mail by our readers and authors and they will help with the balance between different geographical areas in the Journal. Please check the Journal website and the printed version that shows the organization of the Editorial Board and offices.

SICOT is 90 years old and International Orthopaedics turns forty-five. As a major general science journal "International Orthopaedics" has been a catalyst for change and we foresee this continuing for the future. We sincerely hope that the pandemic crisis will be managed in a satisfactory way, letting us to resume a "normal" activity. We are however prepared to adapt and work in different conditions, based on the premise of helping and assisting our fellow colleagues and caregivers to provide the best health for the patients and contributing to a safer environment for all of us.

\section{References}

1. Slullitel PA, Lucero CM, Soruco ML, Barla JD, Benchimol JA, Boietti BR, Zanotti G, Comba F, Taype-Zamboni DR, Carabelli GS, Piccaluga F, Sancineto CF, Diehl M, Buttaro MA, HipFEIR [Hip Fracture in the Elderly - Institutional Register] Study Group (2020) Prolonged social lockdown during COVID-19 pandemic and hip fracture epidemiology. Int Orthop 8:1-9. https://doi.org/ 10.1007/s00264-020-04769-6

2. Dunkerley S, Thelwall C, Omiawele J, Smith A, Deo S, Lowdon I (2020) Patient care modifications and hospital regulations during the COVID-19 crisis created inequality and functional hazard for patients with orthopaedic trauma. Int Orthop 7:1-5. https://doi.org/ 10.1007/s00264-020-04764-x

3. Rajasekaran RB, Kotecha S, Whitwell D, Cosker TDA, Critchley P, Fries CA, Pigott D, Gibbons CLMH, Carr A (2020) Patient safety associated with the surgical treatment of bone and soft tissue tumours during the COVID-19 pandemic-results from an observational study at the Oxford Sarcoma Service. Int Orthop 29:1-6. https://doi.org/10.1007/s00264-020-04736-1

4. Megaloikonomos PD, Thaler M, Igoumenou VG, Bonanzinga T, Ostojic M, Couto AF, Diallo J, Khosravi I (2020) Impact of the COVID-19 pandemic on orthopaedic and trauma surgery training in Europe. Int Orthop 21:1-9. https://doi.org/10.1007/s00264-020$04742-3$

5. Mavrogenis AF, Quaile A, Scarlat MM (2020) The virus crisis affects Orthopaedic surgery and scientific activities worldwide. Int Orthop 44(5):813-817. https://doi.org/10.1007/s00264-02004557-2 
6. Druel T, Andeol Q, Rongieras F, Bertani A, Bordes M, Alvernhe A (2020) Evaluation of containment measures' effect on orthopaedic trauma surgery during the COVID-19 pandemic: a retrospective comparison between 2019 and 2020. Int Orthop 21:1-6. https:// doi.org/10.1007/s00264-020-04712-9

7. Spoletini G, Bianco G, Graceffa D, Lai Q (2020) Transplantation during the COVID-19 pandemic: nothing noble is accomplished without danger. BMC Gastroenterol 20(1):259. https://doi.org/10. 1186/s12876-020-01401-0

8. Bouche PA, Valteau B, Dumaine V, Lang E, Michel K, Eyrolle L, Auberger G, Anract P, Hamadouche M (2020) Were protective procedures against SARS-CoV-2 effective in an orthopaedic and trauma centre during the lockdown period? A retrospective study. Int Orthop 16:1-6. https://doi.org/10.1007/s00264-020-04729-0

9. Cheng FF, Zhan SH, Xie AW, Cai SZ, Hui L, Kong XX, Tian JM, Yan WH (2020) Anxiety in Chinese pediatric medical staff during the outbreak of Coronavirus Disease 2019: a cross-sectional study. Transl Pediatr 9(3):231-236. https://doi.org/10.21037/tp.2020.04. 02

10. Xiong Y, Zhang Q, Sun D, Zhu W (2020) Clinical and CT characteristics of healthcare workers with COVID-19: A single-centered, retrospective study. Medicine (Baltimore) 99(30):e21396. https:// doi.org/10.1097/MD.0000000000021396

11. Skoda EM, Teufel M, Stang A, Jöckel KH, Junne F, Weismüller B, Hetkamp M, Musche V, Kohler H, Dörrie N, Schweda A, Bäuerle A (2020) Psychological burden of healthcare professionals in Germany during the acute phase of the COVID-19 pandemic: differences and similarities in the international context. J Public Health (Oxf) 7:fdaa124. https://doi.org/10.1093/pubmed/fdaa124

12. Khanduja V, Scarlat MM (2020) Reaching a new 'normal' after COVID pandemic and orthopaedic implications. Int Orthop 44(8): 1449-1451. https://doi.org/10.1007/s00264-020-04725-4

13. Dunkerley S, Thelwall C, Omiawele J, Smith A, Deo S, Lowdon I (2020) Patient care modifications and hospital regulations during the COVID-19 crisis created inequality and functional hazard for patients with orthopaedic trauma. Int Orthop 7:1-5. https://doi.org/ 10.1007/s00264-020-04764-x

14. Hernigou J, Valcarenghi J, Safar A, Ferchichi MA, Chahidi E, Jennart H, Hernigou P (2020) Post-COVID-19 return to elective orthopaedic surgery-is rescheduling just a reboot process? Which timing for tests? Is chest CT scan still useful? Safety of the first hundred elective cases? How to explain the "new normality health organization" to patients? Int Orthop 19:1-9. https://doi.org/10. 1007/s00264-020-04728-1

15. Hernigou J, Cornil F, Poignard A, El Bouchaibi S, Mani J, Naouri JF, Younes P, Hernigou P (2020) Thoracic computerised tomography scans in one hundred eighteen orthopaedic patients during the COVID-19 pandemic: identification of chest lesions; added values; help in managing patients; burden on the computerised tomography scan department. Int Orthop 44(8):1571-1580. https://doi.org/10. 1007/s00264-020-04651-5

16. Vaid S, McAdie A, Kremer R, Khanduja V, Bhandari M (2020) Risk of a second wave of Covid-19 infections: using artificial intelligence to investigate stringency of physical distancing policies in North America. Int Orthop 44(8):1581-1589. https://doi.org/10. 1007/s00264-020-04653-3

17. Vaid S, Kalantar R, Bhandari M (2020) Deep learning COVID-19 detection bias: accuracy through artificial intelligence. Int Orthop 44(8):1539-1542. https://doi.org/10.1007/s00264-020-04609-7

18. Rubinger L, Gazendam A, Ekhtiari S, Nucci N, Payne A, Johal H, Khanduja V, Bhandari M (2020) Maximizing virtual meetings and conferences: a review of best practices. Int Orthop 44(8):14611466. https://doi.org/10.1007/s00264-020-04615-9

19. Zagra L, Faraldi M, Pregliasco F, Vinci A, Lombardi G, Ottaiano I, Accetta R, Perazzo P, D'Apolito R (2020) Changes of clinical activities in an orthopaedic institute in North Italy during the spread of COVID-19 pandemic: a seven-week observational analysis. Int Orthop 44(8):1591-1598. https://doi.org/10.1007/s00264-02004590-1

20. De Mauro D, Rovere G, Smimmo A, Meschini C, Mocini F, Maccauro G, Falez F, Liuzza F, Ziranu A (2020) COVID-19 pandemic: management of patients affected by SARS-CoV-2 in Rome COVID Hospital 2 Trauma Centre and safety of our surgical team. Int Orthop 15:1-5. https://doi.org/10.1007/s00264-020-04715-6

21. Luengo-Alonso G, Pérez-Tabernero FG, Tovar-Bazaga M, Arguello-Cuenca JM, Calvo E (2020) Critical adjustments in a department of orthopaedics through the COVID-19 pandemic. Int Orthop 44(8):1557-1564. https://doi.org/10.1007/s00264-02004647-1

22. Zhu Y, Chen W, Xin X, Yin Y, Hu J, Lv H, Li W, Deng X, Zhu C, Zhu J, Zhang J, Ye F, Chen A, Wu Z, Ma Z, Zhang X, Gao F, Li J, Wang C, Zhang Y, Hou Z (2020) Epidemiologic characteristics of traumatic fractures in elderly patients during the outbreak of coronavirus disease 2019 in China. Int Orthop 44(8):1565-1570. https:// doi.org/10.1007/s00264-020-04575-0

23. Wu W, Xiong W, Kang H, Guo Q, Fang Z, Li F (2020) Challenges and response in the medical management of the orthopaedic department during the coronavirus disease 2019 pandemic: strategies in Wuhan, China. Int Orthop 44(8):1489-1495. https://doi.org/10. 1007/s00264-020-04626-6

24. Tempski P, Danila AH, Arantes-Costa FM, Siqueira MAM, Torsani MB, Martins MA (2020) The COVID-19 pandemic: time for medical teachers and students to overcome grief. Clinics (Sao Paulo) 75:e2206. https://doi.org/10.6061/clinics/2020/e2206

Publisher's note Springer Nature remains neutral with regard to jurisdictional claims in published maps and institutional affiliations. 